\title{
Recent case histories of the application of the empirical destressability index methodology
}

\author{
P. Andrieux Itasca Consulting Canada, Canada \\ J. Hadjigeorgiou University of Toronto, Canada
}

A. Sampson-Forsythe Vale Limited, Canada (previously with Xstrata Nickel, Canada)

B. Simser Xstrata Nickel, Canada

A. Turichshev Itasca Consulting Canada, Canada

R. Brummer Itasca Consulting Canada, Canada

\begin{abstract}
The destressability index methodology for the assessment of the likelihood of success of large-scale confined destress blasts in underground mine pillars was developed empirically, based on documented case studies in hard rock mines. Since its introduction it has been successfully employed to design such blasts at several seismically active mines. This article presents two recent case histories of the application of this methodology. The first case study was at the Fraser Copper Mine in the Sudbury Basin, where a choked destress blast was detonated to stress-shadow a seismically active cut-and-fill mining horizon. Vibrating wire stress cell data were recorded over a period of two years after the blast, which shed some light on the stress remobilisation process that followed this choked destress blast. The second case study was at the Onaping Mine, also in the Sudbury Basin, where a deep seismically active remnant waste pillar was targeted.
\end{abstract}

\section{Introduction}

The empirical destressability index methodology was developed between 2001 and 2005, and has since been formally used at least four occasions. This technique quantifies the likelihood of success of a large-scale choked destress blast in an underground mine pillar, for given rock mass conditions and a given stress regime. Because the approach was presented in detail in previous publications, its description will not be repeated here. Please refer to Andrieux and Hadjigeorgiou (2008) for extensive background and detailed methodology, and to Andrieux et al. (2004) for a more succinct description. More detail can be found on the application of the Rock Engineering Systems methodology at large, and to the topic of destress blasting in particular, in Hudson (1992) and Andrieux et al. (2003), respectively. The back-analysis of two well documented case histories have also been reported, one at Brunswick Mine (Andrieux, 2005) and one at Fraser Mine (Andrieux, 2005; Andrieux et al., 2007).

This paper focuses on the description of two additional well documented case histories of the application of the methodology, one blast having been detonated on 22 August 2006 at the Xstrata Nickel Fraser Mine in the 42-1-1620 Stope D7 Lens in Cut 25, and the other on 17 February 2007 at the bottom of the Xstrata Nickel Onaping Mine in a waste pillar between levels 57-0 and 57-1.

\section{Xstrata Nickel Fraser Mine - destress blast in the 42-1-1620 D7 Lens (Cut 25)}

A large-scale choked panel destress blast was detonated in December 2001 at the Fraser Copper Mine in the A5-Right / 42-1-080 Access Pillar area, a region of the mine exploited by an overhand cut-and-fill method. The extraction of Cut 21 had been affected by heavy seismicity, which resulted in this cut taking much longer to mine than previous cuts in the region. The redistribution of ground stresses around the 42-1-1620 Stope as mining progressed upwards into the 39 Sill Pillar below the mined out horizon above, was identified 
as the main contributor to the high level of seismicity, which was expected to further increase with each successive cut. Based on these considerations and given the lack of flexibility in this area, a large-scale choked panel destress blast was implemented. The specific objective of this blast was to deflect the high mining-induced stresses in the 42-1-1620 Stope at least two cuts above Cut 22 (the next one to be exploited), away from mining activity. Figure 1 shows a composite plan view of the A5 stringer and the location of the destress blastholes. This blast design was back-analysed with the destressability index method and is described in detail by Andrieux (2005) and Andrieux et al. (2007).

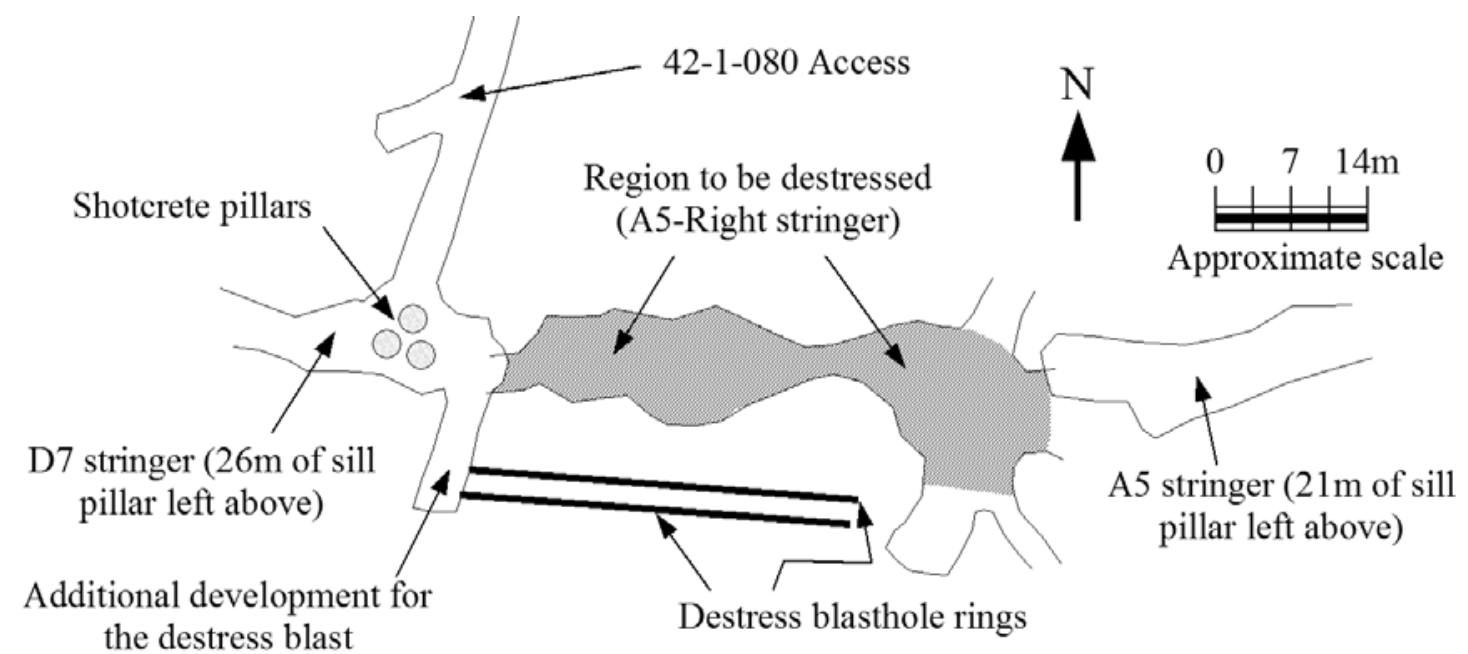

Figure 1 Composite plan view showing the A5 stringers and the location of the December 2001 destress blast in the A5-Right / 42-1-080 Access Pillar area (after Andrieux et al., 2007)

This blast, which was associated with a normalised destressability index score of 0.77 , corresponding to a 'Good' chance of success, worked well. The seismic response, as well as measurements in nearby stress cells and strain gauges, was consistent with the blast having caused a stress redistribution higher up in the sill pillar and in the abutments, away from the next mining cuts. More convincingly yet, the subsequent extraction of cuts 22, 23 and 24 was associated with relatively easy mining conditions, with no large seismic events and minimal work stoppages. Cut 25 however approached the region where the destress blast of December 2001 had concentrated additional load, which resulted in the reoccurrence of heavy seismicity and deteriorating mining conditions. The worsening situation led to the decision to detonate another large-scale choked destress blast in the 42-1-1620 Stope off Cut 25, towards the D7 Lens, in an attempt to secure easier mining in the remainder of the sill pillar.

\subsection{Design of the destress blast}

Similar to the December 2001 blast, the summer 2006 destress blast was designed to create a damage zone in the hanging wall of the A5 and D7 stringers, in order to prevent high mining-induced ground stresses from building up in the sill pillar, and redistribute them instead into the abutments. The ultimate objective was to reduce the potential for rockbursting in the remaining mining cuts.

The location of the destress slot was a challenge due to the numerous excavations in the area and their complex geometry, the need to minimise additional development, and the necessity to keep the explosive charges at least $5 \mathrm{~m}$ away from any ore lens. This $5 \mathrm{~m}$ stand-off distance was meant to 1) eliminate the risk of later encountering undetonated explosives while developing a cut, and 2) avoid excessive damage in the immediate vicinity of the ore lenses, which could destabilise their walls during mining. There was also the requirement to stay clear of the blastholes from the December 2001 destress blast, some of which could conceivably still contain undetonated explosives. The target slot, which was eventually drilled from the east side of the high stress zone, had to be rotated, angled and adjusted a few times until its location satisfied all the constraints set forth. Its extent was also reduced in order to keep it away from existing and future excavations. 
A total of fifty (50) $102 \mathrm{~mm}$ (4 inch) diameter blastholes (totalling 1,110 m [3,642 ft] of drilling) were used, arranged in two parallel rows $2.5 \mathrm{~m}$ apart, the longest hole being $29.3 \mathrm{~m}$ (the self imposed limit of $30 \mathrm{~m}$ was quite aggressive given the $102 \mathrm{~mm}$ diameter of the holes) and the shortest $16.0 \mathrm{~m}$. These holes were fan drilled from a single location, which required careful collar management. The toes of the holes in each row were kept $2.5 \mathrm{~m}$ apart where possible. (Each hole was surveyed and it is the survey results that are discussed here.)

The holes were all loaded with fully-coupled Orica Handi-Bulk ${ }^{\circledR}$ booster-sensitive emulsion (with a density of $1.25 \mathrm{~g} / \mathrm{cm}^{3}$ and an absolute weight strength of $858 \mathrm{cal} / \mathrm{g}$ ). The measured collar lengths varied between 3.5 and nearly $18 \mathrm{~m}$, and were adjusted to avoid excessive explosive energy in the collar region, where the holes were converging. No decking was used along the holes. The longest charge was $25.6 \mathrm{~m}$, which corresponded to nearly $260 \mathrm{~kg}$ of emulsion, and the shortest was $6.3 \mathrm{~m}$ for a charge of only about $64 \mathrm{~kg}$. A total of approximately $7,750 \mathrm{~kg}$ of explosives was used. The holes were detonated in pairs every $25 \mathrm{~ms}$ using Orica I-kon ${ }^{\circledR}$ electronic detonators, for a total blast duration of $625 \mathrm{~ms}$. The maximum instantaneous charge fired was about $515 \mathrm{~kg}$, at $500 \mathrm{~ms}$.

The region directly targeted by the destress blast (i.e. comprised within the two rows of blastholes) had a volume of $2,860 \mathrm{~m}^{3}$. Considering the external zone of influence of ' 16 times the blastholes diameter' (Blake et al., 1998), the total effective volume targeted was close to $6,585 \mathrm{~m}^{3}$. At a rock density of $2.70 \mathrm{t} / \mathrm{m}^{3}$, the total targeted mass was about 17,780 tonnes. Hence, the unit explosive energy of the blast was $(6,642 \times$ $10^{6}$ calories $\left.\div 17,780,000 \mathrm{~kg}\right) \approx 373.6 \mathrm{cal} / \mathrm{kg}$, within the boundaries of 350 and $500 \mathrm{cal} / \mathrm{kg} \mathrm{recommended} \mathrm{by}$ Brummer and Andrieux (2002) for large-scale choked panel destress blasts.

\subsection{Assessment of the destressability index}

Although the design just described was largely based on the December 2001 blast, which gave good results, it was verified with the destressability index methodology to ensure a 'Good' likelihood of success. Table 1 summarises the values associated with the properties retained in the methodology to quantify the eight parameters taken to control the outcome of a large-scale choked destress blast. No numerical modelling work was done for this project to estimate the pre-blast stress levels - instead, the magnitude of the mininginduced principal stress components $\sigma_{1}$ and $\sigma_{3}$ at the time of the destress blast were analytically assessed, based on field observations of borehole breakouts and previous numerical modelling work by Pierce and Board (1999a, 1999b).

The required design values can be calculated as follows:

$$
\begin{aligned}
& \mathrm{E}_{\text {Rock Mass }}=\mathrm{E}_{\text {Laboratory }} \times\left(\left[0.000028 \times \mathrm{RMR}^{2}\right]+\left[0.009 \times \mathrm{e}^{\{\mathrm{RMR} / 22.82\}}\right]\right)=74.8 \mathrm{GPa} \\
& \mathrm{GSI}=\mathrm{RMR}-5=85-5=80 \\
& \mathrm{~m}_{\text {Rock Mass }}=\mathrm{m}_{\text {Laboratory }} \times \mathrm{e}^{([\mathrm{GSI}-100] / 28)}=7.83 \text { (undisturbed, before the destress blast) } \\
& \mathrm{s}_{\text {Rock Mass }}=\mathrm{s}_{\text {Laboratory }} \times \mathrm{e}^{([\mathrm{GSI}-100] 9)}=0.108 \text { (undisturbed, before the destress blast) } \\
& \sigma_{\mathrm{c} \text { Rock Mass }}=\sigma_{3}+\left(\left[\mathrm{m}_{\text {Rock Mass }} \sigma_{\mathrm{c}} \sigma_{3}\right]+\left[\mathrm{s}_{\text {Rock Mass }} \sigma_{\mathrm{c}}{ }^{2}\right]\right)^{0.5}, \text { for } \sigma_{3}=0, \text { which is } 65.7 \mathrm{MPa} \\
& \left.\sigma_{\mathrm{T} \text { Rock Mass }}=\left(\mathrm{m}_{\text {Rock Mass }} \sigma_{\mathrm{c}}-\left[\mathrm{m}_{\text {Rock Mass }}{ }^{2}{\sigma_{\mathrm{c}}}^{2}-4 \mathrm{~s}_{\text {Rock Mass }}{\sigma_{\mathrm{c}}}^{2}\right]^{0.5}\right) / 2 \text { (the quadratic formulae for } \sigma_{1}=0\right) \text {, } \\
& \quad \text { which is about } 2.8 \mathrm{MPa} \\
& \mathrm{B}_{1}=\sigma_{\mathrm{c} \text { Rock Mass }} / \sigma_{\mathrm{T} \text { Rock Mass }}=(65.7 / 2.8)=23.5 \\
& \text { Proximity to failure }=\sigma_{1} /\left(\sigma_{3}+\left[\mathrm{m}_{\text {Rock Mass }} \sigma_{\mathrm{c}} \sigma_{3}+\mathrm{s}_{\text {Rock Mass }} \sigma_{\mathrm{c}}{ }^{2}\right]^{0.5}\right)=19.5 \% \\
& \text { Charge confinement ratio }=(\mathrm{T}+\mathrm{C}) /(\mathrm{D} / 1000)=88 \\
& \text { Unit energy in the blast } \mathrm{E}_{\text {Unit }}=373.6 \mathrm{cal} / \mathrm{kg} \text { of rock. }
\end{aligned}
$$


Table 1 List of the basic properties and quantities required for the assessment of the destressability index associated with the $D 7$ blast

\begin{tabular}{|c|c|c|c|}
\hline Property & Symbol & Unit & $\begin{array}{l}\text { Value in } \\
\text { D7 Blast }\end{array}$ \\
\hline Density of the rock & $\rho_{\mathrm{r}}$ & $\mathrm{kg} / \mathrm{m}^{3}$ & 2,700 \\
\hline Young's modulus of the intact rock material & $\mathrm{E}_{\text {Laboratory }}$ & $\mathrm{GPa}$ & 130 \\
\hline Unconfined compressive strength of the intact rock material & $\sigma_{\mathrm{c} \text { Laboratory }}$ & $\mathrm{MPa}$ & 200 \\
\hline Rock mass rating in the target area & $\mathrm{RMR}_{89}$ & - & 85 \\
\hline Hoek-Brown parameter $m$ of the intact rock material & $\mathrm{m}_{\text {Laboratory }}$ & - & 16.0 \\
\hline Hoek-Brown parameter s of the intact rock material & $\mathrm{S}_{\text {Laboratory }}$ & - & 1.000 \\
\hline $\begin{array}{l}\text { Effective } \sigma_{1} \text { component at the time of the destress blast } \\
\text { (estimated) }\end{array}$ & $\sigma_{1 \text { Actual }}$ & $\mathrm{MPa}$ & 50 \\
\hline $\begin{array}{l}\text { Effective } \sigma_{3} \text { component at the time of the destress blast } \\
\text { (estimated) }\end{array}$ & $\sigma_{3 \text { Actual }}$ & $\mathrm{MPa}$ & 30 \\
\hline $\begin{array}{l}\text { Angle of incidence of the blast with respect to the } \sigma_{1} \\
\text { component }\end{array}$ & $\theta$ & degrees & 90 \\
\hline Length of the pillar to destress & $\mathrm{L}$ & $\mathrm{m}$ & 42.4 \\
\hline Height of the pillar to destress & $\mathrm{H}$ & $\mathrm{m}$ & 21.2 \\
\hline Number of blasting rings in the destress blast & $\mathrm{N}$ & \# & 2 \\
\hline Diameter of the blastholes & $\mathrm{D}$ & $\mathrm{mm}$ & 101.6 \\
\hline Distance between blasthole rings & $\mathrm{B}$ & $\mathrm{m}$ & 2.5 \\
\hline Distance between blastholes on the same ring & $\mathrm{S}$ & $\mathrm{m}$ & 2.5 \\
\hline Unloaded toe length in the blastholes ${ }^{1}$ & $\mathrm{~T}$ & $\mathrm{~m}$ & 0.0 \\
\hline Unloaded collar length in the blastholes & $\mathrm{C}$ & $\mathrm{m}$ & $8.9^{2}$ \\
\hline Usage of inert stemming material & - & Yes or No & No \\
\hline Density of the explosive product & $\rho_{\mathrm{e}}$ & $\mathrm{g} / \mathrm{cm}^{3}$ & 1.25 \\
\hline Absolute weight strength of the explosive & AWS & $\mathrm{cal} / \mathrm{g}$ & 858 \\
\hline
\end{tabular}

${ }^{1}$ Non-breakthrough holes. $\quad{ }^{2}$ Derived from average values in the fanned blastholes.

Table 2 summarises the rating and score associated with each parameter for the assessment of the destressability index in the D7 blast. 
Table 2 Rating and score associated with each parameter for the assessment of the destressability index in the $\mathrm{D} 7$ blast

\begin{tabular}{lllllc}
\hline Parameter & Property & \multicolumn{2}{l}{ Value } & \multicolumn{2}{l}{ Rating $\times$ Cause $=$ Score } \\
\hline $\mathrm{P}_{1}-$ Stiffness of the rock mass & $\mathrm{E}_{\text {Rock Mass }}$ & 74.8 & 2 & 13 & 26 \\
$\mathrm{P}_{2}-$ Brittleness of the rock mass & $\mathrm{B}_{1}$ ratio & 23.5 & 2 & 13 & 26 \\
$\mathrm{P}_{3}-$ Degree of fracturing of the rock mass & RMR $_{89}$ & 85 & 2 & 14 & 28 \\
& $\begin{array}{l}\text { Proximity to the } \\
\text { H-B envelope }\end{array}$ & $19.5 \%$ & 0 & 14 & 0 \\
$\mathrm{P}_{4}-$ Proximity to failure & $\begin{array}{l}\text { Angle from the } \\
\text { blast axis to } \sigma_{1}\end{array}$ & $90^{\circ}$ & 2 & 13 & 26 \\
$\mathrm{P}_{5}-$ Orientation with respect to $\sigma_{1}$ & $\begin{array}{l}\text { Number of blast } \\
\text { rings }\end{array}$ & 2 & 1 & 18 & 18 \\
$\mathrm{P}_{6}-$ Width of the target zone & $\begin{array}{l}\text { Energy per unit } \\
\text { mass }\end{array}$ & 373.6 & 2 & 24 & 48 \\
$\mathrm{P}_{7}-$ Explosive energy per tonne of rock & $\begin{array}{l}\text { Blasthole } \\
\text { diameter ratio }\end{array}$ & 88 & 2 & 17 & 34 \\
$\mathrm{P}_{8}-$ Confinement of the charges & & Total & & 206 \\
\hline
\end{tabular}

The corresponding normalised overall score was thus $(206 \div 252)=0.82$, which corresponds to a destressability index of 'Good', as sought after.

\subsection{Results of the destress blast}

The destress blast was detonated on Monday 22 August 2006 at 04:37 EDT, at the end of night shift. The blast vibrations monitored with high frequency surface-mounted geophones indicated that all the charges were initiated over the specified $625 \mathrm{~ms}$. Immediately following the blast, there was a significant increase in the local seismic activity, with twenty-nine (29) events recorded in the first hour after the blast. The event frequency did not stabilise to background levels until after 08:30 on Tuesday 23 August, about 28 hours after the blast. Of the 120 events that were recorded during this time, two (2) on 22 August had magnitudes greater than $\mathrm{M}_{\mathrm{N}}$ (Nuttli magnitude) 1.0:one at 06:44 had a $\mathrm{M}_{\mathrm{N}}$ of 1.6, and one at 21:42 had a $\mathrm{M}_{\mathrm{N}}$ of 2.3. Three vibrating wire borehole stress cells purposely installed in the area also showed significant drops at blast time, which clearly indicate a major change in the local stress field. More comments on these measurements are provided in Section 2.4.

The area was inspected by Xstrata Nickel personnel during the morning of 23 August. Overall, ground conditions were good, with the unavoidable collateral damage restricted to the targeted area. Approximately 1,000 tonnes of material had been displaced into the drill drift, but no significant damage had been inflicted to the ground support system (Figure 2). There was also no damage to surrounding mine openings, and no visible failure of the ground support in adjacent stope headings. The mining crews were allowed to re-enter all the areas that had been proactively closed in the vicinity of the destress blast at 09:30 on 23 August, 29 hours after the blast.

Based on the location of the triggered seismicity, field observations, instrumentation measurements, and the relatively easy subsequent mining, the destress blast can be considered a success. It undoubtedly created a damaged zone in the 42-1-1620 Stope, which significantly impeded the build-up of mining-induced stresses in the area. These results are in accordance with expectations given the destressability index of 'Good' associated beforehand with the blast. 


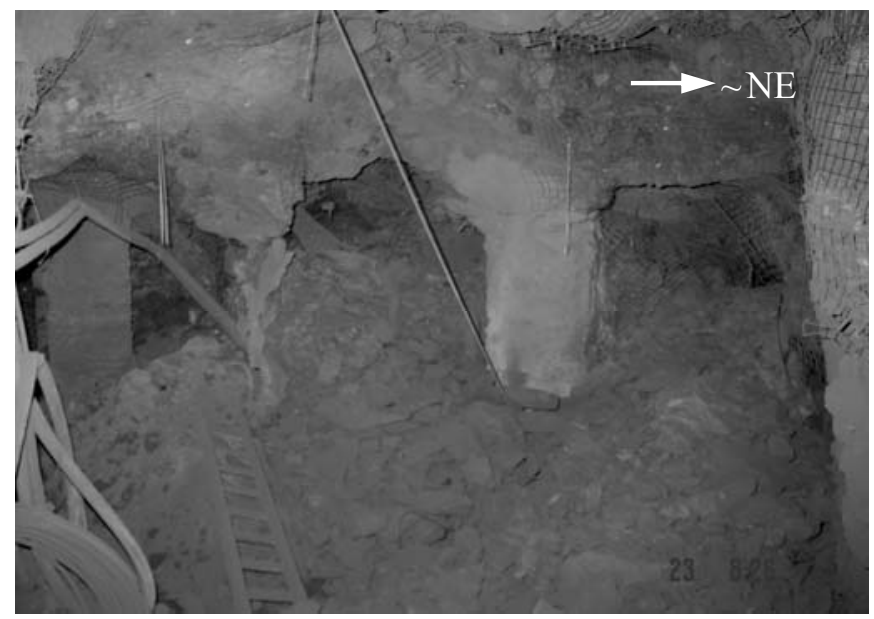

Figure 2 Photograph looking approximately north-west towards the area from where the destress blast was drilled and loaded, showing the significant ejection of rock that resulted (notice how fine the ejected material is)

\subsection{Long-term behaviour of the local stress field}

The three stress cells installed in the vicinity of the destress blast were monitored over a period of more than two years after the blast. Figure 3 shows the readings obtained from these instruments, installed behind the area targeted by the D7 blast. The first spikes (in June 2006) were from the breakage of the cables to all three instruments, due to a scoop tram hit.

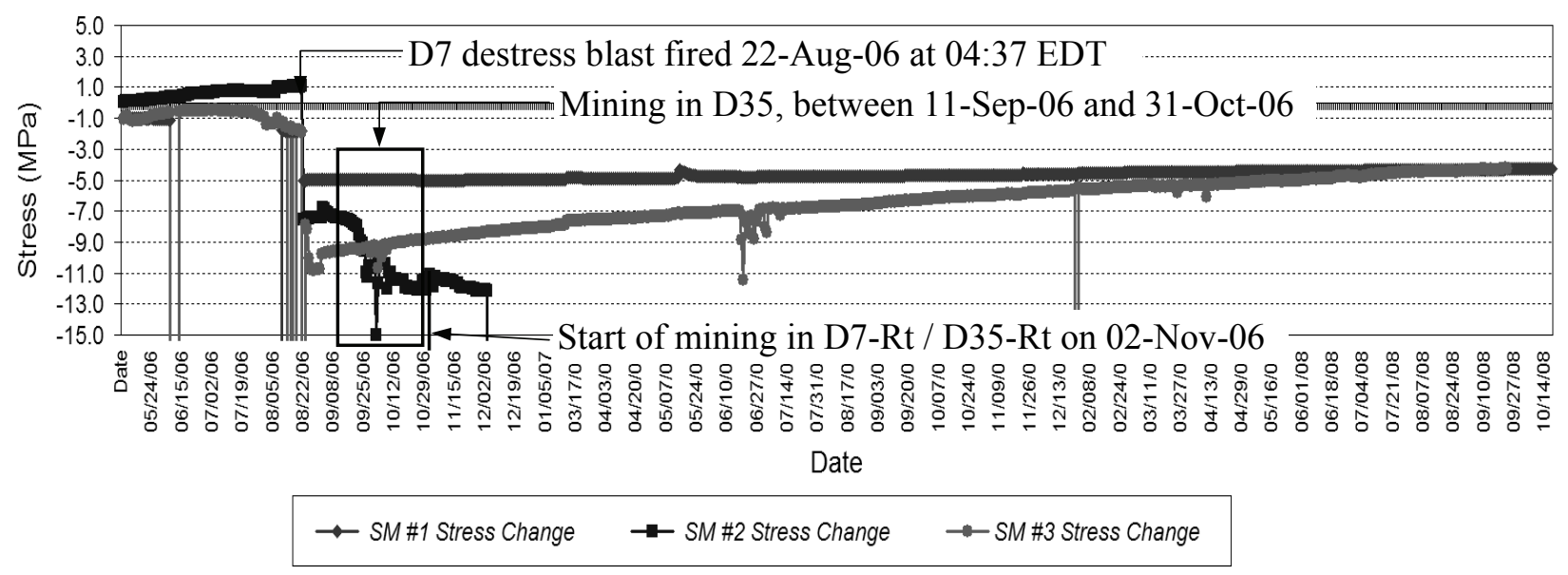

Figure 3 Readings (converted to MPa) of the three vibrating wire stress cells installed in the vicinity of the $\mathrm{D} 7$ destress blast

Cell \#2, located towards the west side of the destress blast, was showing a steady stress increase before the blast. Cells \#1 and \#3, located towards the east side of the blast, had originally shown stress increases, but started to show a decrease by early July, presumably due to rock mass failure in their vicinity. The data then clearly show how the destress blast caused an instantaneous drop of up to $9.5 \mathrm{MPa}$ in the stress field at the locations where these instruments were installed. Note that these gauges rarely measure the actual magnitude of the local $\sigma_{1}$ component, unless the installation boreholes were drilled normal to the $\sigma_{1}$ plane, and the gauges themselves were installed with their vibrating wire also perpendicular to $\sigma_{1}$. As a result, the actual stress changes are generally larger than measured by this type of stress cell - the stress drop at gauge \#3 was thus likely greater than the $9.5 \mathrm{MPa}$ measured. Cell \#2 showed further stress reductions that clearly correspond to mining operations in the nearby D35 and D7-Right / D35 Right lenses. Cell \#1 stabilised at $-5 \mathrm{MPa}$, but, interestingly, Cell \#3 indicated a progressive stress increase over a period of about two years, towards the $-5 \mathrm{MPa}$ reading of nearby Cell \#1. This increase is interpreted as a progressive remobilisation of 
the stress - should the wedge of Cell \#3 have slipped, it is likely that the reading would have stabilised 1) more quickly, and 2) towards a reading of 0 instead of $-5 \mathrm{MPa}$. The question of stress remobilisation after a large-scale choked destress blast is often raised and the data collected from the D7 destress blast indicated that this remobilisation had occurred in this case over a period of two years. One would also intuitively expect this phenomenon to occur more readily along the outer edge of the destress blast, near the toe of the blind holes.

\section{$3 \quad$ Xstrata Nickel Onaping Mine - destress blast in the 892 Stope between 57-1 and 57-0}

This case study describes a much smaller choked panel destress blast, which involved only six (6) blastholes. The recovery of the last remnant reserves at the Xstrata Nickel Onaping Mine (in the form of the 892 Stope located at the very bottom of the mine between levels 57-2 sub and 57-0 sub) was undertaken first with blastholes drilled downwards between 57-1 sub and 57-0 sub, then blastholes drilled upwards from 57-1 sub. The entire lens was originally thought to be ore, but, following the inspection of blastholes with a geophysics probe, two distinct blocks were found to be Felsic Gneiss waste plugs. Mining around, and leaving in place, these plugs would have left two stress windows at the very bottom of the mine, an area already highly stressed due to the wrapping of the ground stresses beneath the extracted ore body. These two pillars were not expected to fail on their own due to their rather squat shape (about $10 \mathrm{~m}$ in strike length, by $10 \mathrm{~m}$ hanging wall-to-footwall, by $17 \mathrm{~m}$ in height (grey areas in Figure 4a)).

The main concern was the subsequent development of a second drift, north of, and parallel to, the first one, for the drilling of the upwards blastholes. This second access was planned at a lower elevation in order to locate it in the stress shadow caused by the first pass of mining, between 57-1 sub and 57-0 sub (Figure 4b). It was anticipated that this development would not be achievable in the pillar areas, where it would be subjected to very high lateral stress concentrations. Since mining these waste blocks would have rendered the recovery of the 892 Stope uneconomic, the decision was made to destress them with two choked destress blasts, one in each pillar but detonated at different times. This paper focuses on the destress blast that was implemented in the western pillar.

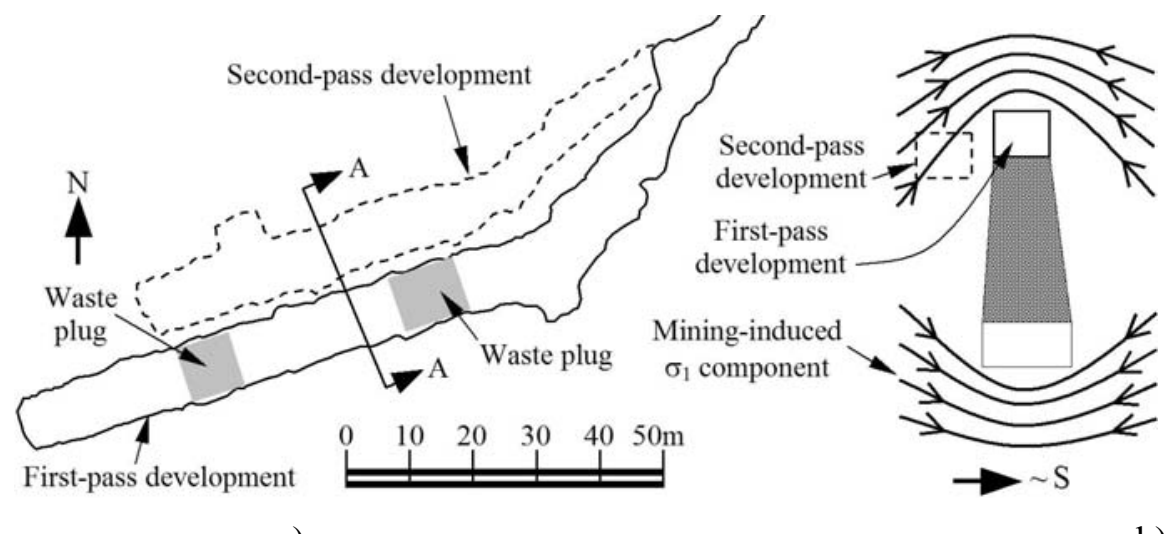

a)

b)

Figure 4 a) Plan view (to scale) showing the drifts as eventually driven and cross section;

b) Schematic cross-section A-A (not to scale) showing the stress-shadowing effect sought after by the mining approach for the recovery of Stope 892 at Onaping Mine

\subsection{Design of the destress blast}

The destress slot was located directly in the targeted pillar - since there were no plans to return to the area after the blast, damage to the vicinity was not an issue. Only six (6) parallel $70^{\circ}$ south-dipping $114 \mathrm{~mm}$

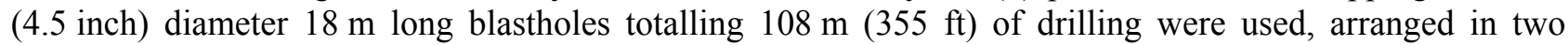
parallel rows $2.5 \mathrm{~m}$ apart, with the toes of the holes in each row also $2.5 \mathrm{~m}$ apart. The holes were loaded with continuous (without any decking) fully coupled Orica Handi-Bulk emulsion, the same product used in the case study previously discussed. Each hole had a $3 \mathrm{~m}$ collar. A total of nearly 1,040 kg of explosives were used. 
As for the Fraser Copper Mine case study, the holes were detonated in pairs every 25 ms using Orica I-kon electronic detonators, for a total blast duration of only $75 \mathrm{~ms}$ and a maximum instantaneous charge per delay of about $345 \mathrm{~kg}$. Considering the external zone of influence of ' 16 times the blastholes diameter', the total effective volume targeted was close to $735 \mathrm{~m}^{3}$. At a rock density of $2.80 \mathrm{t} / \mathrm{m}^{3}$, the total targeted mass was about 2,050 tonnes. The unit explosive energy of the blast was $\left(891 \times 10^{6}\right.$ calories $\left.\div 2,050,000 \mathrm{~kg}\right) \approx$ $434.6 \mathrm{cal} / \mathrm{kg}$, well within the suggested 350 to $500 \mathrm{cal} / \mathrm{kg}$ range. The destress blast was fired concurrently with an inverse drop raise, for a total blast duration of as much as $6.95 \mathrm{~s}$.

\subsection{Assessment of the destressability index}

The design of the blast was elaborated by incrementally verifying it with the destressability index methodology, with the objective of obtaining a minimum rating of 'Good'. Table 3 summarises the values associated with the Onaping blast and the properties chosen to quantify the eight parameters selected in the methodology to control the outcome of a large-scale choked destress blast.

Table 3 List of the basic properties and quantities required for the assessment of the destressability index associated with the Onaping blast

\begin{tabular}{|c|c|c|c|}
\hline Property & Symbol & Unit & $\begin{array}{l}\text { Value in } \\
\text { Blast }\end{array}$ \\
\hline Density of the rock & $\rho_{\mathrm{r}}$ & $\mathrm{kg} / \mathrm{m}^{3}$ & 2,800 \\
\hline Young's modulus of the intact rock material & $\mathrm{E}_{\text {Laboratory }}$ & $\mathrm{GPa}$ & 74 \\
\hline Unconfined compressive strength of the intact rock material & $\sigma_{\mathrm{c} \text { Laboratory }}$ & $\mathrm{MPa}$ & 225 \\
\hline Rock mass rating in the target area & $\mathrm{RMR}_{89}$ & - & 80 \\
\hline Hoek-Brown parameter $m$ of the intact rock material & $\mathrm{m}_{\text {Laboratory }}$ & - & 27.0 \\
\hline Hoek-Brown parameter s of the intact rock material & $\mathrm{S}_{\text {Laboratory }}$ & - & 1.000 \\
\hline Effective $\sigma_{1}$ component at the time of the destress blast & $\sigma_{1 \text { Actual }}$ & MPa & $122^{1}$ \\
\hline Effective $\sigma_{3}$ component at the time of the destress blast & $\sigma_{3 \text { Actual }}$ & MPa & $23^{1}$ \\
\hline $\begin{array}{l}\text { Angle of incidence of the blast with respect to the } \sigma_{1} \\
\text { component }\end{array}$ & $\theta$ & degrees & 90 \\
\hline Length of the pillar to destress & $\mathrm{L}$ & $\mathrm{m}$ & 7.0 \\
\hline Height of the pillar to destress & $\mathrm{H}$ & $\mathrm{m}$ & 17.0 \\
\hline Number of blasting rings in the destress blast & $\mathrm{N}$ & \# & 2 \\
\hline Diameter of the blastholes & $\mathrm{D}$ & $\mathrm{mm}$ & 114.3 \\
\hline Distance between blasthole rings & $\mathrm{B}$ & $\mathrm{m}$ & 2.5 \\
\hline Distance between blastholes on the same ring & $\mathrm{S}$ & $\mathrm{m}$ & 2.5 \\
\hline Unloaded toe length in the blastholes & $\mathrm{T}$ & $\mathrm{m}$ & 1.5 \\
\hline Unloaded collar length in the blastholes & $\mathrm{C}$ & $\mathrm{m}$ & 3.0 \\
\hline Usage of inert stemming material & - & Yes or No & Yes \\
\hline Density of the explosive product & $\rho_{\mathrm{e}}$ & $\mathrm{g} / \mathrm{cm}^{3}$ & 1.25 \\
\hline Absolute weight strength of the explosive & AWS & $\mathrm{cal} / \mathrm{g}$ & 858 \\
\hline
\end{tabular}

${ }^{1}$ Derived from 3D numerical modelling work carried out by the Craig Mine Ground Control Department.

The required design values can be calculated with the same equations shown in Section 2.2. Table 4 summarises the rating and score associated with each parameter for the assessment of the destressability index of the destress blast. 
Table 4 Rating and score associated with each parameter for the assessment of the destressability index associated with the Onaping west pillar destress blast

\begin{tabular}{lllllc}
\hline Parameter & Property & \multicolumn{2}{l}{ Value } & \multicolumn{2}{c}{ Rating $\times$ Cause $=$ Score } \\
\hline $\mathrm{P}_{1}-$ Stiffness of the rock mass & $\mathrm{E}_{\text {Rock Mass }}$ & 35.4 & 1 & 13 & 13 \\
$\mathrm{P}_{2}-$ Brittleness of the rock mass & $\mathrm{B}_{1}$ ratio & 43.2 & 2 & 13 & 26 \\
$\mathrm{P}_{3}-$ Degree of fracturing of the rock mass & RMR & 80 & 2 & 14 & 28 \\
& $\begin{array}{l}\text { Proximity to the } \\
\text { H-B envelope }\end{array}$ & $45.7 \%$ & 1 & 14 & 14 \\
$\mathrm{P}_{4}-$ Proximity to failure & $\begin{array}{l}\text { Angle from the } \\
\text { blast axis to } \sigma_{1}\end{array}$ & 90 & 2 & 13 & 26 \\
$\mathrm{P}_{5}-$ - Orientation with respect to $\sigma_{1}$ & $\begin{array}{l}\text { Number of blast } \\
\text { rings }\end{array}$ & 2 & 1 & 18 & 18 \\
$\mathrm{P}_{6}-$ Width of the target zone & $\begin{array}{l}\text { Energy per unit } \\
\text { mass }\end{array}$ & 434.6 & 2 & 24 & 48 \\
$\mathrm{P}_{7}-$ Explosive energy per tonne of rock & $\begin{array}{l}\text { Blasthole } \\
\text { diameter ratio }\end{array}$ & 52 & 2 & 17 & 34 \\
$\mathrm{P}_{8}-$ Confinement of the charges & & & & & \\
\hline
\end{tabular}

The corresponding normalised overall score is thus $207 \div 252=0.82$ (similar to the Fraser Copper Mine case study described in Section 2), which corresponds to the required destressability index of 'Good'.

\subsection{Results of the destress blast}

The blast was detonated on Saturday morning 17 February 2007 at 03:20 EST. The blast-induced vibrations captured by the mine-wide ESG seismic network, although saturated, indicated a $6.98 \mathrm{~s}$ duration. Figure 5 shows the seismicity recorded around the 892 Stope during the three days following the destress blast - the absence of seismicity in the targeted waste pillar can be interpreted as a sign of success.

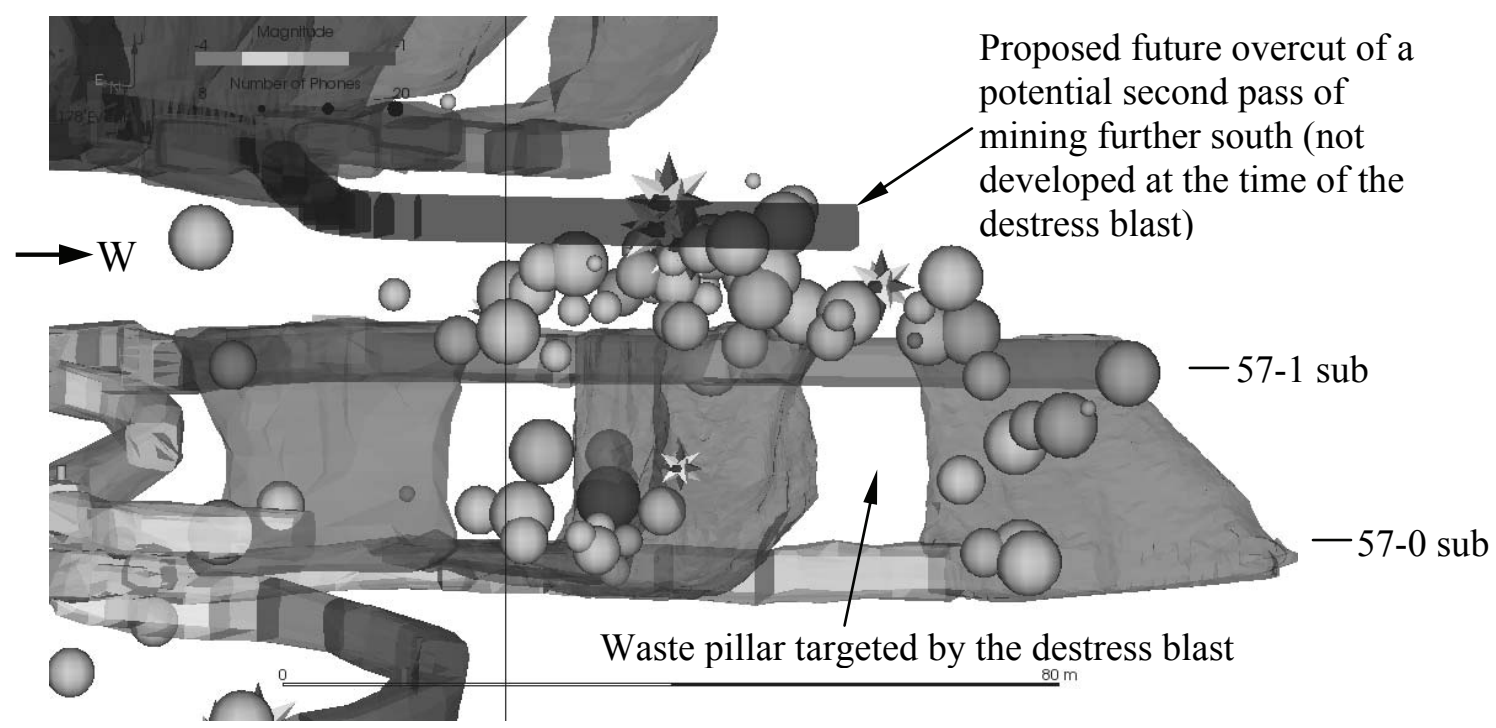

Figure 5 Elevation view looking south showing the seismicity recorded around the 892 Stope during the three days following the destress blast. Stars are the blasts (as point sources picked by the seismic system), including the inverse drop raise halfway to the level above 1 sub (after Simser, 2007) 
The area of the destress blast could not be visually examined because of its location past the inverse drop raise. Overall, the indications available seemed to indicate that the destress blast worked. The east waste pillar was also destressed at a later date, and mining in the area was ultimately successful and carried out under manageable stress conditions. Certainly, the second access, from which the upholes were drilled, was driven without any significant stress problems and essentially no stress spalling, contrary to what was usually observed in other development in the area. These results matched the expectation from the 'Good' destressability index established beforehand.

\section{Concluding remarks}

Five years after its introduction, the destressability index methodology continues to be tested at operating mines. Two new case studies have been presented in this paper, both successful in the sense that the outcome 'predicted' by the calculated index was in agreement with the field results observed. These case studies are further evidence that the methodology has practical value in the sense that it can help design a large-scale confined destress blast simply by taking steps that result in an increase of the destressability index.

So far, all the destressability index case studies concerned situations where a 'Good' destressing effect was anticipated - this is normal considering the time, resources, costs and efforts involved in the implementation of such a blast (no operating mine is likely to embark on such an endeavour without a good chance of success). It would nevertheless be useful to document cases where large-scale choked destress blasts have failed, and back-analyse their associated destressability index values.

The data collected for the Fraser Copper Mine case study presented in section 2 seem to indicate that, as intuitively expected, ground stresses eventually remobilise in the destressed area, but that the process takes time. As a result, there seems to be a limit to the amount of time a destress blast can be detonated ahead of mining in the area.

\section{Acknowledgements}

The authors are grateful to $\mathrm{Mr} \mathrm{W}$. Greg Maybee of Xstrata Nickel for providing them with the data on the long-term behaviour of the stress cells installed near the destress blast in the 42-1-1620 Stope D7 Lens at the Fraser Copper Mine. The authorisation by Xstrata Nickel management to publish the results presented in this paper is also gratefully acknowledged.

\section{References}

Andrieux, P. and Hadjigeorgiou, J. (2008) The Destressability Index Methodology for the Assessment of the Likelihood of Success of a Large-Scale Confined Destress Blast in an Underground Mine Pillar, International Journal of Rock Mechanics and Mining, March 2008, Vol. 45(3), pp. 407-421.

Andrieux, P., Hadjigeorgiou, J. and Sampson-Forsythe, A. (2007) The Destressability Index for the Design of LargeScale Choked Destress Blasts in Mine Pillars: Application to the Fraser Mine 42-1-080 Destress Blast, in Challenges in Deep and High Stress Mining, Y. Potvin, J. Hadjigeorgiou, T.R. Stacey (eds.), Australian Centre for Geomechanics, Perth, Australia, pp. 487-493.

Andrieux, P. (2005) Application of Rock Engineering Systems to Large-Scale Confined Destress Blasts in Underground Mine Pillars, doctoral thesis, Laval University, Faculty of Engineering, Department of Mining, Metallurgical and Materials Engineering, Quebec, Canada, 414 p.

Andrieux, P., Hadjigeorgiou, J. and Brummer, R. (2004) A Rock Engineering Systems Approach to Destress Rock Blasting, in Challenges in Deep and High Stress Mining, Y. Potvin, J. Hadjigeorgiou, T.R. Stacey (eds), Perth, Australian Centre for Geomechanics, Perth, Australia, pp. 479-486.

Andrieux, P., Hadjigeorgiou, J. and Brummer, R. (2003) Rock Engineering Systems and Destress Rock Blasting, in Proceedings 105th Annual General Meeting of the Canadian Institute of Mining, Metallurgy and Petroleum (CIM), Montreal, Canada, 13 p.

Blake, W., Board, M. and Brummer, R. (1998) Destress Blasting Practices - A Review of the Literature and Current Industrial Practice, report from the Itasca Consulting Group and Richard Brummer Associates to CAMIRO Mining Division, Sudbury, Canada, $96 \mathrm{p}$.

Brummer, R. and Andrieux, P. (2002) A Design Methodology for Destress Blasting, in NARMS-TAC 2002: Mining and Tunnelling Innovation and Opportunity, R. Hammah, W. Bawden, J. Curran, M. Telesnicki (eds), Toronto, Ontario, Canada, Toronto : University of Toronto Press, 2002, Vol. 1, pp. 165-172. 
Hudson, J.A. (1992) Rock Engineering Systems: Theory and Practice, Ellis Horwood Series in Civil Engineering Geotechnics, New York, USA, 185 p.

Pierce, M. and Board, M. (1999a) Modelling of Sill Pillar Extraction in the Deep Copper Zone of Strathcona Mine, technical report from the Itasca Consulting Group to Falconbridge, Ltd., Minneapolis, USA, $30 \mathrm{p}$.

Pierce, M. and Board, M. (1999b) Modelling of Sill Pillar Extraction in the Deep Copper Zone of Strathcona Mine Additional Recommendations, technical report from the Itasca Consulting Group to Falconbridge, Ltd., Minneapolis, USA, $27 \mathrm{p}$.

Simser, B. (2007) Onaping 57-1 to 57-0 Destress Blast, internal technical memorandum, Xstrata Nickel Craig/Onaping Mining Complex, Onaping (Sudbury), Canada, 2 p. 
